logos_i_ethos_1_(32)_2012, s. 157-174

\title{
Dobrosław Kot
}

\section{Człowiek we wnętrzu metafor}

Minęło 10 lat od śmierci Józefa Tischnera i przez ten czas wiele na temat jego koncepcji człowieka zostało powiedziane. Jego filozofowanie wokół spraw ludzkich jest uporządkowane, wydaje się, że wy-

Dobrosław Kot - dr filozofii, adiunkt w Katedrze Filozofii Uniwersytetu Ekonomicznego w Krakowie. Współzałożyciel Instytutu Myśli Józefa Tischnera. Ostatnio opublikował książkę Podmiotowość i utrata (2009). lowiono wszystkie istotne momenty tej myśli. Próby takie podejmowali: Barbara Skarga, Adam Węgrzecki, Karol Tarnowski, Tadeusz Gadacz, Aleksander Bobko, Adam Workowski i wielu innych. Nie ma sensu zatem powtarzać ich tez lub podążać tymi samymi tropami. Warto natomiast na wstępie przywołać te węzłowe punkty, aby zobaczyć, co jeszcze w filozofii Józefa Tischnera czeka na wyświetlenie.

Józef Tischner konsekwentnie posługiwał się pojęciem „filozofia człowieka", zamiast przyjętym w tradycji fenomenologicznej, z której się wywodził, pojęciem „antropologii filozoficznej”. Tę konsekwencję widać było $\mathrm{w}$ nazwie katedry ${ }^{1}$, którą kierował na Papieskiej Akademii Teologicznej, nazwie przedmiotu, który wykładał ${ }^{2}$ oraz tytułach podręczników, które przygotowywał dla swoich studentów ${ }^{3}$. Na czym polegają różnice pomiędzy filozofią człowieka a antropologią? Tischner miał świadomość, jak fenomenologia rozumie zadania antropologii. Jego prace nie potwierdzają zainteresowania kwestią miejsca człowieka w kosmosie, a zwłaszcza dociekaniem, jaka jest istota

1 Zob. Wydział Filozofii Papieskiej Akademii Teologicznej (prezentacja), opr. T. Gadacz, A. Michalik, W. Skoczny, „Logos i Ethos”, 1991, nr 1, s. 167.

Zob. tamże, s. 165.

Zob. J. Tischner, Wybrane problemy filozofii człowieka, Kraków 1985; tenże, Filozofia człowieka dla duszpasterzy i artystów, [w:] tenże, Myślenie w żywiole piękna, Kraków 2004, s. 139-336. 
człowieka, które miałoby polegać na poszukiwaniu zespołu właściwości odróżniających go od świata zwierząt. Nie znaczy to jednak, że Tischnerowi obcy był problem ludzkiej istoty człowieka, zawarty w klasycznym pytaniu: „kim jest człowiek?”. Zapewne ze względu na te różnice Tischner posługiwał się terminem „filozofia człowieka”, przyglądając się uważnie człowiekowi, który staje wobec rozmaitych dziedzin rzeczywistości. $W$ jakimś sensie można więc powiedzieć, że centrum tej filozofii jest „człowiek w świecie”. Jest to człowiek, który staje wobec wartości, wobec drugiego człowieka, wreszcie - wobec Boga. Te trzy zagadnienia organizowały refleksję Tischnera. Można postawić hipotezę - choć jej sprawdzenie wymagałoby osobnego studium - że w swej filozofii człowieka Józef Tischner stał na stanowisku relacyjnym: jego drogą do rozumienia człowieka było wyświetlenie rozmaitych relacji, w które człowiek wchodzi. Relacje te są niezwykle istotne dla uchwycenia tego, kim on jest. I jednocześnie są dla samego Tischnera jakąś próbą wyjścia poza substancjalistyczną koncepcję człowieka, którą wielokrotnie krytykował ${ }^{4}$.

Badacze myśli Tischnera chętnie dokonują periodyzacji jego filozofii ${ }^{5}$. Przyjmuje się, że można wyodrębnić trzy okresy ${ }^{6}$, które odróżnia od siebie zarówno krąg inspiracji myślenia, jak i metody. Te różnice mają oczywiście znaczenie w rozumieniu człowieka i jego świata.

Pierwszy okres to czas silnych inspiracji fenomenologicznych, wyrastających jeszcze z tradycji myślenia Romana Ingardena. Widać to zarówno w podejmowanej tematyce: podmiotowość, wartości, aksjologia, próba zbudowania koncepcji "Ja" aksjologicznego, ale także w formie językowej. Techniczny, pełen fenomenologicznego żargonu język w niczym nie przypomina mowy Tischnera znanej z lat osiemdziesiątych czy dziewięćdziesiątych. Teksty $\mathrm{z}$ tego okresu zostały zebrane $\mathrm{w}$ zbiorze

$4 \quad$ Zob. tenże, Filozofia człowieka dla duszpasterzy i artystów, dz. cyt., s. 163n; tenże, Wybrane problemy filozofii człowieka, dz. cyt., s. 8n; Człowiek przez okna systemu, [w:] tenże, Myślenie według wartości, Kraków 1993, s. 353n.

Zob. A. Bobko, Poszukiwanie prawdy o człowieku, „Znak”, 2001, nr 3 (550), s. 56-70.

Zob. tenże, Wstęp. Józefa Tischnera myślenie o człowieku, [w:] J. Tischner, O człowieku. Wybór pism filozoficznych, Wrocław - Warszawa - Kraków 2003, s. XVIIn. 
Świat ludzkiej nadziei ${ }^{7}$, a także częściowo w zbiorze Myślenie według wartośc $i^{8}$. Jednak najpełniej widać to myślenie w rozprawie habilitacyjnej Fenomenologia świadomości egotycznej ${ }^{9}$.

Drugi okres to zdecydowane zwrócenie się Tischnera w stronę filozofii dialogu. Wtedy pojawiają się silne inspiracje myślą Emmanuela Levinasa i Franza Rosenzweiga. Dla Tischnera kluczowe staje się pojęcie spotkania, drugiego człowieka, Twarzy. Ten okres owocuje Filozofia dramatu ${ }^{10}$, gdzie zmienia się nie tylko sposób mówienia o człowieku, ale też sam język. Tischner pokazuje rozmaite ludzkie dramaty, za pomocą nowej siatki pojęć-metafor chce opisać człowieka w jego relacjach z innymi.

Wreszcie trzeci okres jego myślenia o człowieku, rozpoczęty Sporem o istnienie człowieka ${ }^{11}$, pokazuje coraz większy wpływ myślenia religijnego. Józef Tischner wprowadza do języka swej filozofii człowieka pojęcia przejęte wprost $z$ teologii: łaska, zbawienie. Centralną kategorią staje się dobro, a niegdysiejszy - znany z okresu pierwszego - horyzont aksjologiczny zostaje zastąpiony horyzontem agatologicznym. Ten okres jest bodaj najbardziej tajemniczy. Autor Sporu podejmuje wątki, których choroba i przedwczesna śmierć nie pozwoliły mu ukończyć. Widać więc jedynie zarys głębokiej zmiany w myśleniu, w tym w myśleniu o człowieku. Perspektywy, które ten zwrot otwiera, są ledwie zarysowane.

Można się spierać, czy te trzy okresy rozdzielone są rewolucjami w myśleniu samego Tischnera, czy też przejście pomiędzy nimi jest płynne. Niewątpliwie każda $\mathrm{z}$ tych zmian ustawia myślenie o człowieku w nieco innej perspektywie. Warto natomiast wskazać na coś innego. Obok tej treściowej ewolucji widać bowiem jeszcze jedną, najczęściej traktowaną mniej poważnie. Przy porównywaniu prac wcześniejszych - powstałych do roku mniej więcej 1978 - z tymi późniejszymi widać wyraźną przemianę stylistyki. Wczesny Tischner pełen był

Zob. J. Tischner, Świat ludzkiej nadziei, Kraków 1975.

Zob. tenże, Myślenie według wartości, dz. cyt.

Zob. tenże, Fenomenologia świadomości egotycznej, [w:] tenże, Studia z filozofii świadomości, Kraków 2006, s. 131-418.

10 Zob. tenże, Filozofia dramatu. Wprowadzenie, Kraków 1998.

$11 \quad$ Zob. tenże, Spór o istnienie człowieka, Kraków 1998. 
precyzyjnego języka fenomenologii, zwieńczeniem tego okresu jest jego rozprawa habilitacyjna. Później dość rygorystyczny język rozluźnia się, Tischner często sięga do języka metafory i symbolu, wtedy też zaczynają się pojawiać w jego tekstach pojęcia-klucze - tak istotne w filozofii późnego Tischnera - Twarz, dramat, spotkanie, obietnica. Są one dalekie stylistycznie od frazeologii fenomenologicznej.

Najczęściej w środowisku uczniów Tischnera ta przemiana komentowana jest w sposób prosty: Tischner coraz lepiej władał językiem; Tischner potrzebował swobodniejszych pojęć do opisania doświadczeń, którymi się zajmował, doświadczeń z pogranicza filozofii, duszpasterstwa i publicystyki; Tischner dusił się w sztywnym gorsecie fenomenologicznego żargonu. Wszystkie te tłumaczenia przypisują nowemu językowi wprawdzie nieprzypadkowe, ale też niespecjalnie istotne miejsce ${ }^{12}$.

Czy chodzi tylko o zmiany stylistyczne, czy też metaforyczność języka odsyła do poważniejszego problemu?

W okolicach 1980 r. Tischner ogłasza trzy teksty, które mogą być odczytywane jako swoisty manifest filozoficzny. Tischner, myśliciel 50-letni, mający już za sobą prace pisane na stopień naukowy, próbuje zadać sobie samemu pytanie, czym jest i czym będzie refleksja, którą uprawia. We wstępie do zbioru Myślenie według wartości próbuje problematyzować własne filozofowanie, unikając jednak identyfikacji z jakimkolwiek „-izmem”. Te trzy teksty - zawarte w przywołanym zbiorze - to właśnie tytułowe Myślenie według wartości $i^{13}$, ale też Myślenie religijne ${ }^{14}$ i artykuł najbardziej interesujący z perspektywy niniejszego szkicu: Myślenie $z$ wnętrza metafory ${ }^{15}$. Te trzy Myślenia próbują opisać samorozumienie filozoficzne Tischnera $\mathrm{z}$ tamtego okresu.

12 Opinie te dość często pojawiają się w rozmowach i swobodnych konwersacjach, dlatego trudno wskazać konkretne artykuły, które podejmują to zagadnienie. Pozwoliłem sobie na przywołanie tego stanowiska po to, by wskazać pewien klimat, który tworzy się wokół myślenia Józefa Tischnera.

${ }_{13}$ Zob. J. Tischner, Myślenie według wartości, [w:] tenże, Myślenie według wartości, dz. cyt., s. 506-523.

14 Zob. tenże, Myślenie religijne, [w:] tenże, Myślenie wedlug wartości, dz. cyt., s. 357-382.

15 Zob. tenże, Myślenie z wnętrza metafory, [w:] tenże, Myślenie według wartości, dz. cyt., s. $490-505$. 
Tekst Myślenie $z$ wnętrza metafory to próba odpowiedzi na pytanie o miejsce metafory w filozoficznym myśleniu. Pojawia się tam kilka interesujących tropów, które potem znajdą swoją kontynuację w późniejszych tekstach Tischnera. Pokazują one, że swoista metoda jego filozofowania nie była ozdobnikiem, lecz wypływała z przekonań o naturze metafizycznej. Ponieważ wiele napisano już o filozofii człowieka stworzonej przez Józefa Tischnera, nie warto powtarzać znanych już tez. Zamiast więc pytać o CO owej refleksji nad człowiekiem, warto postawić pytanie o JAK.

Jak Tischner myśli o człowieku, w jakie słowa i struktury ubiera swoje refleksje? Co mogą oznaczać te wieloznaczne metafory, które jednych uwodzą swym pięknem, innych natomiast drażnią swą nieprecyzyjnością? Ten szkic poświęcony będzie jednemu problemowi: jak Józef Tischner myśli o człowieku.

\section{Wnętrza metafor}

Kiedy przyglądamy się metaforyczności na poziomie wyrazu językowego, to naturalnym przeciwieństwem tego sposobu opisu świata wydaje się dosłowność. Metaforze zostaje więc przeciwstawione pojęcie. Pojęcie jest precyzyjne, jednoznaczne, ma ono dużą przejrzystość; metafora z kolei jest wieloznaczna, nieprzejrzysta. Temu przeciwstawieniu odpowiada wedle Tischnera głębsze napięcie, które ma charakter metafizyczny ${ }^{16}$.

Na tym poziomie metaforyczności przeciwstawiona jest faktyczność. Faktyczność - a więc zakładana w naturalnym nastawieniu lub w oglądzie zdroworozsądkowym struktura świata - daje się wyrazić prostym sformułowaniem: rzeczy są tym, czym się wydają, świat jest taki, jaki jest doświadczany. Świat jest zbiorem faktów i w tym sensie jest on rzeczywistością ostateczną. Tłumaczy się sam przez siebie, nie potrzebuje żadnych zewnętrznych „nieświatowych” wyjaśnień.

Zmiana w nastawieniu do rzeczywistości zmienia się radykalnie, kiedy człowiek powie sobie, że rzeczy być może nie są tym, czym się wydają. Najwyraźniejszy przykład takiej problematyzacji pojawia się u Platona 
w kontekście paraboli jaskini: świat jest tylko cieniem świata, rzeczy są cieniami prawdziwej rzeczywistości ${ }^{17}$. Tak więc dopiero poczucie pewnej nieoczywistości oraz towarzyszące mu poczucie nieostateczności zastanej w faktyczności światowości uruchamia metaforyzację. Metaforyzacja jest próbą adekwatnego opisania tej zagadkowości napotkanej w świecie. Jeśli faktyczność zostaje postawiona pod znakiem zapytania, to również pojęcie - ze swoją jasnością i przejrzystością - zostaje zakwestionowane. Skoro to, co widzimy, jest tylko jakimś pozorem, jakimś odbiciem, nie jest rzeczywistością samą, zatem do opisu potrzeba innych środków. I tu pojawia się metafora. Metaforyczność na poziomie językowym odzwierciedla jedynie pewną metaforyczność świata na poziomie metafizycznym. O ile łatwo pokazać strukturę metafory na poziomie językowym i jej relację do pojęcia (dosłownego znaczenia), o tyle pokazanie metaforyczności na poziomie metafizycznym nastręcza pewne trudności.

Rozważmy to na przykładzie. Paul Ricoeur, analizując symbolikę zła, rozważa następujący schemat ${ }^{18}$. Mamy dosłowne znaczenie "plamy”, odniesione do pewnego stanu fizycznego. Słowo „plama” zostaje wzięte z porządku potocznego; nazywa ono pewien nieskomplikowany stan faktyczny. To dosłowne znaczenie zostaje przeniesione na inne pole: plama oznacza winę, grzech; wina jest jakby plamą. To drugie znaczenie nie jest dosłowne, a jednocześnie to pierwsze nie zostaje zupełnie zatarte. Psalmista prosząc Boga: „obmyj mnie zupełnie z mojej winy, oczyść mnie z grzechu mojego!"19, gra tymi dwoma znaczeniami. To jest jedna strona tego procesu metaforyzacji: przeniesienie dosłownego znaczenia na płaszczyznę symboliczną. Nałożenie dwóch płaszczyzn i ich ciągłe występowanie obok siebie sprawia, że symbol zachowuje swoją nieprzejrzystość. Tym różni się od czysto umownego znaku. Ricoeur jest dla Tischnera ważnym punktem odniesienia, bywa przywoływany w wielu tekstach, między innymi w Myśleniu $z$ wnętrza metafory ${ }^{20}$.

17 Zob. Platon, Państwo, tłum. W. Witwicki, Warszawa 1994, t. 2, s. 57n. oraz: M. Heidegger, Platona nauka o prawdzie, tłum. S. Blandzi, [w:] tenże, Znaki drogi, Warszawa 1999, s. 179-189.

Zob. P. Ricoeur, Symbolika zła, tłum. S. Cichowicz, M. Ochab, Warszawa 1986, s. 17n. Ps 51, 4, cytat za Biblią Tysiąclecia.

20 Zob. J. Tischner, Myślenie $z$ wnętrza metafory, dz. cyt., s. 503. 
Jest jednak jeszcze druga strona tego procesu, może mniej interesująca z perspektywy hermeneutycznej - która zastaje już świat opisany symbolami - a niezwykle istotna w optyce fenomenologicznej. U podstaw symbolu winy, która jest jakby plamą, jest jakieś doświadczenie własnej grzeszności. Nieskonceptualizowane, nienazwane, ale domagające się jakiegoś wyrazu. Człowiek czegoś doświadcza, a jednocześnie czuje, że rzeczywistość, której dotknął, nie daje się zamknąć w prostych słowach, nie daje się opisać dosłownymi znaczeniami. Rzeczywistość zła domaga się zatem nie pojęcia, lecz metafory. Na tym etapie można chyba powiedzieć, że świat ludzkiego doświadczenia dzieli się na dwie dziedziny: opisywaną pojęciami (wielbłąd, owca, namiot, studnia) i opisywaną symbolami. Ta druga domaga się symbolicznego wyrazu, gdyż ma w sobie pewną tajemniczość, nieprzejrzystość. Nieprzejrzysta jest miłość, nieprzejrzysta jest wina, nieprzejrzyste jest wszelkie sacrum. Opisywanie tej dziedziny pojęciami byłoby ich zafałszowaniem.

Żeby uściślić te rozważania, warto wprowadzić rozróżnienie na to, co symbolizowane, i to, co symbolizujące. W przypadku winy jako plamy wina jest symbolizowana jako plama, a plama jest tym, co symbolizujące w odniesieniu do doświadczenia winy.

Takie rozumienie symbolu ${ }^{21}$ wyraźnie pokazuje, że nie może być on pojmowany jako „protopojęcie”. Symbol nie podlega więc prostemu odczarowaniu zgodnemu z zasadą: niegdyś ludzie tworzyli symbole, gdyż nie potrafili przemyśleć np. problematyki zła, dziś możemy rozwinąć te symbole w pojęcia, uczynić pierwotnie nieprzejrzyste przejrzystym. Symbol zawsze pozostaje ciemny i nieprzejrzysty ${ }^{22}$, działa na nasze rozumienie zupełnie inaczej niż klarowne, przezroczyste pojęcie.

W szczególnych sytuacjach dziedzina metaforyczności obejmuje cały świat, stawiając pod znakiem zapytania wszelkie pojęciowe ujęcia.

${ }^{21}$ Na potrzeby niniejszego szkicu używam tu pojęć „metafora” i „symbol” zamiennie, podobnie jak robi to w swoich tekstach Józef Tischner. Był on świadomy różnicy pomiędzy nimi, jednak - jak sam zauważył - Paul Ricoeur sam utożsamił je ze sobą. Zob. J. Tischner, Myślenie $z$ wnętrza metafory, dz. cyt., s. 503.

22 Zob. P. Ricoeur, Egzystencja i hermeneutyka, tłum. S. Cichowicz i in., Warszawa 1985 , s. 62 n. 
Widać to choćby w metaforyce Platońskiej jaskini. Znowu mamy powtórzony znany z Ricoeura schemat. Jest dosłowny sens jaskini, który zostaje przeniesiony na inną płaszczyznę: świat (lub: świat ludzkiego doświadczenia) jest jakby jaskinią - ciemną, odbijającą cienie itd. Obraz ten uzupełnia druga strona procesu metaforyzacji. Świat, który doświadczamy jako jedyny (i w tym sensie ostateczny), nie jest jedyny i ostateczny; nie jest on tym, czym się wydaje w doświadczeniu zmysłowym. Czym jest zatem? Jest cieniem świata, jest odbiciem świata prawdziwego. A skoro tak, skoro bezproblemowe z pozoru doświadczenie świata odsłania nam jakąś jego nieoczywistość, jakąś tajemnicę, trzeba zastąpić pojęcia metaforą. Pojęcia byłyby zafałszowaniem, gdyż dawałyby pozór przejrzystości i swojej samowystarczalności. A zatem symbol swoją nieprzejrzystością odsyła do „innego świata”, do prawdziwej rzeczywistości. Metafory rodzą się zatem z doświadczenia niepewności i nieoczywistości świata. W tym sensie wyrażają one jakąś fundamentalną prawdę filozoficzną.

Innym przykładem totalności myślenia symbolicznego są kultury pierwotne, gdzie każdy fakt jest epifanią, gdzie cała rzeczywistość - a nie tylko pewien wydzielony z niej obszar doświadczeń - staje się manifestacją sacrum, a zatem jest symbolem czegoś innego. W tych przypadkach mamy w pewnym sensie odwrócony kierunek metaforyzacji. Zwykłe drzewo nabiera symbolicznego znaczenia, bo jest przejawem innego świata. Nadal mówimy „drzewo”, ale rzeczywistość, która jest pod tym słowem skrywana, jest dalece bardziej złożona i nieoczywista niż pewien fakt przyrodniczy: struktura tkanek i zachodzących w nich procesów. Jednocześnie owo drzewo nie przestaje być drzewem „z krwi i kości”. Rodzi się pytanie, czy te dwa procesy symbolizacji mają identyczny charakter. W pierwszym niedosłownie rozumiane słowo "plama” stawało się metaforycznym wyrazem dla doświadczenia winy, $\mathrm{w}$ drugim zaś przypadku to samo drzewo odsłania w pewnym doświadczeniu swoją „głębię", stając się symbolem „czegoś więcej”. Gdyby próbować te dwa przypadki rozróżnić fenomenologicznie, a więc wskazać fenomeny dane w doświadczeniu, to w pierwszym mamy doświadczenie winy jako plamy (plama jest tu czymś dodanym), w drugim mamy doświadczenie drzewa jako epifanii sacrum. 
Ten genetyczny porządek jest istotny z perspektywy fenomenologii, natomiast $\mathrm{w}$ gotowym symbolu staje się dla hermeneutyki mniej istotny. Hermeneutyka ma do dyspozycji pewien symbol, który jest żywym napięciem między dosłownością a metaforycznością.

Natomiast ten porządek jest znaczący z perspektywy fenomenologicznej. Co w zmetaforyzowanym świecie jest przedmiotem doświadczenia? Symbole czy doświadczenia, które potem są wyrażane w symbolach? W kontekście filozofii Tischnera jest to sprawa istotna.

W tekście Myślenie $z$ wnętrza metafory Tischner przywołuje kilka metafor. Pokazuje Platońską jaskinię $e^{23}$, wspomina o Kartezjańskim złośliwym demonie ${ }^{24}$ (metafora ta zostanie rozwinięta w Sporze o istnienie człowieka ${ }^{25}$ ), ale szczególne miejsce przyznaje metaforze rodzenia $^{26}$. Tischner przygląda się jej zastosowaniu w kontekście myślenia o Trójcy Świętej. Na poziomie dosłowności rodzenie to pewien proces życia biologicznego. Rodzi się nowe życie, ale dokonuje się to w bólach i cierpieniu rodzącej kobiety. W kontekście Trójcy owo rodzenie zostaje poddane swoistej idealizacji. Bóg nie może cierpieć, więc rodzenie zostaje odklejone od wszelkiego bólu. Mamy więc niedosłowne znaczenie rodzenia. Zostaje nam proces, który opisuje relację między Ojcem a Synem. Dlaczego nie da się ich opisać niemetaforycznie? Argument jest dość oczywisty: sfera Boskości jest nam niedostępna i nieprzejrzysta, wszelkie orzekanie o niej za pomocą przejrzystych pojęć może prowadzić do zafałszowania. Przejrzystym pojęciem byłby np. związek przyczynowo-skutkowy albo kategoria stworzenia. Ale obydwa te ujęcia zapoznają relację współistotności. Syn jako skutek byłby mniej doskonały od Ojca, zaś jako stworzony byłby co najwyżej odbiciem Boga, byłby czymś metafizycznie różnym, tak różnym, jak różne jest stworzenie od Stwórcy. A zatem pozostaje metafora. Do tego momentu symbolika rodzenia powtarza opisywany już powyżej schemat.

\footnotetext{
23 Zob. J. Tischner, Myślenie z wnętrza metafory, dz. cyt., s. 491.

24 Zob. tamże, s. 493.

25 Zob. J. Tischner, Spór o istnienie człowieka, dz. cyt., s. 19n.

26 Zob. tenże, Myślenie z wnętrza metafory, dz. cyt., s. 498n.
} 
Jednak Tischner wskazuje na jeszcze jeden moment: metafora wraca na ziemię. Przetworzona na potrzeby myślenia o Trójcy metafora rodzenia - pozbawiona już momentów bólu i cierpienia - staje się przydatna do opisu innych sfer rzeczywistości, np. rodzenia prawdy. Metafory krążą więc pomiędzy jednym a drugim światem, wracają z powrotem na ziemię, ale już przemienione.

Gdzie więc jest prawdziwe życie metafor? Na pewno nie w zamianie pojęć na „pojęcia miękkie”, czyli metafory. Platon przecież nie przenosi całej swej opowieści na poziom paraboli jaskini. Stara się dać jej objaśnienie, ciągle krąży myślą pomiędzy jednym światem (tajemnicze obcowanie z prawdą idei) a drugim (oślepiony kajdaniarz opuszczający jaskinię). Metafora nie jest więc alegorią, która odwzorowuje w skali 1:1 badany problem. Metafora to ciągłe napięcie pomiędzy dosłownością a metaforycznością. Redukcja metafory do jednego tylko elementu: do samej plamy, jaskini, rodzenia jest zaprzeczeniem tego myślenia. Myślenie z wnętrza metafory to ciągłe wychodzenie i wracanie. Redukcję do samego niedosłownego bieguna metafory można nazwać nadmierną poetyzacją, alegoryzacją. Taki zabieg oddala metaforę od myślenia i od filozofii. Natomiast redukcję do drugiego bieguna - a więc zastąpienie metafor precyzyjnymi pojęciami, Tischner nazywa „terryzmem”27. To uznanie, że świat faktów jest oczywisty, samoobjaśnialny i mający ostateczny charakter. Symbol nie znajduje się na tym samym poziomie, co alegoria.

\section{Trzy metafory antropologiczne}

Powyższe analizy ujawniły Józefa Tischnera jako teoretyka metafory. Nie był on jednak - jak Ricoeur - tropicielem metafor w tekstach kultury. Artykuł Myślenie z wnętrza metafory jest manifestem. Tischner chce myśleć za pomocą metafor, ponieważ sądzi, że tylko tak da się dotknąć tajemnicy doświadczenia, tajemnicy człowieka. Precyzyjny język już go nie pociąga, widzi w nim zagrożenie dla poszukiwań filozoficznych. Metafora wskazuje na niepewność, na nieoczywistość, metafora swoim 
napięciem pomiędzy tym, co dosłowne, a tym, co metaforyczne, oddaje cały dramatyzm świata. Skoro problem człowieka stoi w samym centrum filozofii Tischnera, warto zobaczyć, jakimi metaforami stara się on owego człowieka opisać. Po Tischnerze-teoretyku przychodzi czas na Tischnera-praktyka metafory. Na ile pozostaje wierny swoim teoretycznym ustaleniom? Jak żyją metafory w jego myśleniu?

Spośród wielu metafor, którymi posługuje się Józef Tischner spróbujmy wybrać trzy. Ten wybór ma w sobie pewną arbitralność, ale jednocześnie pozwala ukazać napięcia myślenia metaforycznego.

Jako pierwsza w tym zestawieniu pojawia się metafora pieśni: „Człowiek jest jak płynąca poprzez czas - pieśń”28. Jest on jednocześnie instrumentem i artystą. Sam wyśpiewuje ową pieśń, wyśpiewuje według szczególnej partytury, którą są wartości. W metaforze tej Tischner radykalnie odrzuca substancjalistyczne ujęcie człowieka ${ }^{29}$. Pieśń jest niegotowa, nie da się jej sprowadzić do partytury. Prawdziwa pieśń to pieśń wyśpiewana. Relacje pomiędzy pieśnią a partyturą określa wolność człowieka.

Drugą metaforą jest określenie człowieka jako istoty dramatycznej, co oznacza: „przeżywać dany czas, mając wokół siebie innych ludzi i ziemię jako scenę pod stopami” ${ }^{30}$. Ale też „Być istotą dramatyczną to wierzyć - prawdziwie czy nieprawdziwie - że zguba lub ocalenie są w rękach człowieka" ${ }^{31}$. Ta metafora jest fundamentem całej koncepcji filozofii dramatu, gdzie symbolika teatralna: scena, maska, dramat itd. zostają wykorzystane po to, by opisać człowieka w całości jego egzystencji.

I wreszcie trzecia metafora, która pojawia się w ostatnim okresie twórczości Tischnera. To metafora śmierci człowieka. Sięgając po nią, Tischner wchodzi w dyskusję z tradycją Michela Foucaulta: „człowiek chce dowieść, że to, co robił [zło Auschwitz i Kołymy - D.K.], nie on robił, ponieważ jego nigdy nie było. Tak powstaje idea «śmierci

${ }_{28}$ Tenże, Etyka wartości i nadziei, [w:] D. von Hildebrand, J. A. Kłoczowski, J. Paściak, J. Tischner, Wobec wartości, Poznań 1982, s. 53.

29 Por. tenże, Filozofia człowieka dla duszpasterzy i artystów, dz. cyt., s. 233.

30 Tenże, Filozofia dramatu, dz. cyt., s. 7n.

31 Tamże, s. 10. 
człowieka»" 32 . Ta metafora ma charakter specyficzny: teza śmierci człowieka unieważnia człowieka, kondycją człowieka jest nie-bycie. Tischner widzi wagę i dziejowy charakter doświadczeń dwudziestowiecznych totalitaryzmów. Ale jednocześnie stawia tezę: „nawet jeśli «człowiek umarł» [...], to znaczy, że istniał, a jeśli istniał, to znaczy, że się może narodzić"33. Umarł człowiek, a żyją ludzie. Zatem człowiek żyjący stwierdza śmierć człowieka. To samoodnoszenie wprowadza nowy element do struktury frazy Nietzschego „Bóg umarł”. Tam człowiek orzekał śmierć Boga; tu człowiek orzeka śmierć samego siebie. Można powiedzieć, że to tylko metafora - w znaczeniu alegorii, porównania bez zobowiązań. Śmierć człowieka to kompromitacja jakiegoś modelu człowieczeństwa, jakiegoś ideału człowieka, kres dotychczasowego rozumienia. Ale struktura tej metaforyki jest bardziej złożona: człowiek może przeżyć własną śmierć. Do tego mamy stwierdzenie: jeśli człowiek umarł, to znaczy, że żył; a więc może się odrodzić. Kto się może odrodzić? Ten sam czy inny? Jeśli tamten człowiek umarł, doprowadził się do samozagłady, to dlaczego mielibyśmy go wskrzeszać?

Każda z tych metafor zasługuje na szczegółową analizę. Na razie jednak skoncentrujmy się na ich wspólnej strukturze. Cały czas przedmiotem badań jest nie CO Tischner mówi o człowieku, ale JAK to robi. Mówi o człowieku za pomocą metafor. Czy jednak te metafory przypominają te, które sam przywoływał w Myśleniu z wnętrza metafory?

U Paula Ricoeura nieznane doświadczenie (grzech, wina) zostaje wyjaśnione przez znane pojęcie (plama, zgubienie drogi). To, co symbolizowane, jest niejasne, dlatego potrzebuje tego, co symbolizujące. Symbolizujące wzięte jest z porządku codzienności: plama, zagubienie drogi - to potoczne doświadczenia, które każdy człowiek rozumie. To one mają stać się pomocne w ujęciu tego, co tak trudne do wyrażenia w pojęciach. Tak rodzi się metafora. Podobnie było w przypadku paraboli jaskini. Słuchacz Platona na pewno nie wiedział, czym są idee i jak można je poznać - to przecież wysiłek wieloletniego myślenia dialektycznego i nieprzeciętnej

32 J. Tischner, Spór o istnienie człowieka, dz. cyt., s. 57.

33 Tamże, s. 8. 
przenikliwości samego Platona. Natomiast ten sam słuchacz potrafił sobie bez trudu wyobrazić los kajdaniarza: doświadczenie ciemności i ich rozjaśnienia, towarzyszące temu doświadczenie oślepienia nadmiarem światła - to wydarzenia z codziennego życia każdego z nas. Dzięki temu, co znane, Platon wprowadza w to, co jest tajemnicą.

Jeśli więc Józef Tischner posługuje się w swej filozofii człowieka metaforami, to chce nam powiedzieć przynajmniej tyle, że człowiek jest tajemniczy, nie poddaje się prostym wyjaśnieniom, oraz to, że człowieka nie można zredukować do tego, co tylko ziemskie: redukcja do faktyczności - terryzm - zafałszowuje prawdę o człowieku. Ale poza tymi podobieństwami do struktur symbolicznych badanych przez Ricoeura Tischner proponuje własną drogę, odbiegając nieco od takiego rozumienia metafory. Dokonuje metaforyzacji człowieka, ale jednocześnie to, co u Tischnera symbolizujące, nie pochodzi z porządku potoczności. Wprawdzie człowiek w świecie doświadcza pieśni, teatru i śmierci, i potrafi coś o nich powiedzieć, jednak nietrudno zauważyć, że te symbole mają inny charakter niż plama, zagubienie drogi czy jaskinia. Na czym polega różnica?

Każde z przywołanych przez Tischnera słów samo w sobie ma pewien aspekt nieprzejrzystości. Wprawdzie człowiek doświadcza pieśni: słucha ich i nieraz sam je wykonuje, ale jednocześnie jest w muzyce coś tajemniczego. Wprawdzie muzyka rządzi się matematycznymi harmoniami $^{34}$, ale jednocześnie jest jakimś nieprzeniknionym do końca żywiołem. Jak każda dziedzina sztuki, ma w sobie pierwiastek niemierzalny, irracjonalny, który nie poddaje się prostej analizie. Podobnie jest $\mathrm{z}$ teatrem. W jakimś sensie jest on opisywalny: scena, widownia, aktorzy, odgrywane dramaty, ale jednocześnie to, co dla teatru specyficzne, również sięga do tajemniczych żywiołów. Takie były starożytne funkcje teatru, tak wygląda - bliska przecież Tischnerowi - polska tradycja dramatyczna: Dziady Mickiewicza, Wesele Wyspiańskiego, teatr Grotowskiego, Kantora czy Staniewskiego to ustawiczne mierzenie się z tajemnicą. Teatr wydaje się może nawet bardziej tajemniczy niż sam człowiek. I wreszcie śmierć człowieka. Parafraza słynnej tezy Nietzsche- 
go „Bóg umar’”35, przeniesiona na problem człowieka również próbuje wysłowić pewne niejasne doświadczenie za pomocą słowa, którego sens też wcale nie jest tak oczywisty. Sama śmierć jest dla człowieka tajemnicą, znajduje się poza wszelkim doświadczeniem, napawa grozą, trwogą.

Tischner tworzy więc zupełnie nowe napięcie w swoich metaforach. Nieznane przegląda się w nieznanym, symbol pozostaje nieprzenikniony, zupełnie inaczej, niż w analizach Ricoeura i swoich własnych, teoretycznych badaniach metafory. Tam metafora była wystrzeliwana „w niebo" i potem wracała na ziemię. Tu to, co symbolizujące, nie powraca na ziemię (jeśli przez „ziemię" rozumiemy to, co oswojone, potoczne i jasne). Co zatem chce nam powiedzieć Tischner?

Czy można tu mówić o pomyłce? Czy można przyjąć, że Tischner - uwiedziony wymyśloną przez siebie symboliką - rozminął się z własnym, wypracowanym wcześniej rozumieniem metafory? Takie podejrzenia zawsze są ryzykowne. O pomyłce raczej nie może być mowy, jeśli weźmie się poważnie pod uwagę słowa samego Tischnera. We wstępie do Filozofii dramatu określa cel swych rozważań: „Celem pierwszorzędnym jest przywrócenie słowu dramat właściwego ciężaru gatunkowego"36. Czy Ricoeur próbował przywracać właściwy ciężar słowu „plama”? Nie, jego celem było przebadanie symboliki zła. Plama była prosta i zrozumiała, plama jest gatunkowo mało ważna, o ile nie służy nam lepszemu zrozumieniu fenomenu winy. Zatem celem metaforyzacji nie jest dowartościowywanie symbolizującego, lecz lepsze zrozumienie symbolizowanego.

$\mathrm{U}$ Tischnera ulega to jednak pewnemu pomieszaniu. Wydawałoby się, że celem projektu filozofii dramatu jest raczej pokazanie jakiejś prawdy o człowieku, prawdy doniosłej, wyrażonej w metaforze istoty dramatycznej. Tu jednak widać coś innego: chodzi o lepsze zrozumienie pojęcia dramatu. Tak przedefiniowany cel może jednak sugerować, że podstawowym celem Tischnera jest swoista filozofia teatru. Jeśli pojawi się w niej człowiek, to tylko jako środek do przywrócenia „ciężaru

35 F. Nietzsche, Wiedza radosna, tłum. L. Staff, Warszawa 1906, s. 108.

36 J. Tischner, Filozofia dramatu, dz. cyt., s. 7. 
gatunkowego". Jednak Tischnera nie interesuje teatr jako cel, potwierdzają to wszystkie niemal analizy przywołanej tu książki. Nie interesuje go nawet sam dramat - o ile nie może stać się poręczną metaforą tłumaczenia problemów ludzkiego losu. Mało tego, można nawet zaryzykować hipotezę, że Tischner pisał wstęp do Filozofii dramatu z myślą o zupełnie innych rozważaniach. Pisał na przykład, że substancją dramatu jest czas $^{37}$. Substancją, czyli czymś niezwykle ważnym - podobnie jak w metaforze pieśni czas jest „wewnętrzną rzeczywistością melodii" ${ }^{38}$, niezbędną, by pieśń zaistniała. Ale niewiele znajdziemy analiz czasu i czasowości w samym tekście Filozofii dramatu. Trochę też pisze Tischner o scenie ${ }^{39}$, ale też szybko porzuca ten element metafory. Poza wstępem scena go nie za bardzo interesuje.

Zatem nie człowiek i nie dramat. Jak wybrnąć $\mathrm{z}$ tej pułapki? Metoda Tischnera jest inna. Wydaje się, że przyjęcie w tych trzech ważnych metaforach słów, które same domagają się wyjaśnienia, jest nieprzypadkowe. Te metafory dzieli wiele lat: „pieśń” pierwszy raz pojawia się w połowie lat siedemdziesiątych; metafora „dramatu” pojawia się pod koniec tej samej dekady ${ }^{40}$ i znajduje swoje zwieńczenie w publikacji Filozofi dramatu (pierwsze wydanie - 1990); z kolei analizy „śmierci człowieka" to połowa lat dziewięćdziesiątych. Mamy więc dwie dekady konsekwentnej - i odmiennej od postulowanej teorii - „praktyki metaforyzacyjnej” Tischnera.

Skoro mamy więc nieprzypadkowość - powtarzalność tego samego zabiegu na przestrzeni lat wskazuje na pewną konsekwencję - to wypada zapytać o metodę. Czym jest metafora u Tischnera? Symbolizujące i symbolizowane pozostają w ustawicznym napięciu. Człowiek jest tajemnicą i dramat (pieśń, śmierć) jest tajemnicza. Metafory są budowane po to, by lepiej zrozumieć człowieka. U Tischnera nie jest to tylko zabieg

\footnotetext{
$37 \quad$ Zob. tamże, s. 8.

38 J. Tischner, Filozofia człowieka dla duszpasterzy i artystów, dz. cyt., s. 233.

39 Zob. tenże, Filozofia dramatu, dz. cyt., s. 8n.

40 Trudno wskazać jedno konkretne miejsce, ale na pewno znaczącym krokiem na tym polu był artykuł Tischnera Fenomenologia spotkania, opublikowany w periodyku „Analecta Craco-
} viensia”, R. X, 1978. 
hermeneutyczny. On widzi człowieka jako istotę dramatyczną, on doświadcza ludzkiej egzystencji jako dramatu. Pod tym względem jest niezwykle blisko myślenia samego Ricoeura. Ricoeur odróżniając symbol od alegorii, pisze, że alegoria jest zawsze jakąś hermeneutyką, a symbol nie; symbol pozostaje na innym poziomie, on poprzedza hermeneutykę $e^{41}$. Jeśli dla Tischnera dramat jest tak rozumianą metaforą, to jest on niejako doświadczany, a nie dobierany jako wygodne narzędzie. Gdyby był tylko narzędziem, można byłoby zastąpić go innym narzędziem. Jeśli jednak dramat i dramatyczność są fenomenami ludzkiego doświadczenia, to ich obecność jest nieprzypadkowa. To tłumaczy, dlaczego Tischner artykułuje jako jeden z celów swych analiz przywrócenie pojęciu dramatu ciężaru gatunkowego. Nie jest tak, że celem jego projektu nie jest ani dramat, ani człowiek. Są nim i człowiek, i dramat - jednocześnie. Jeśli przywrócimy słowu dramat właściwy ciężar, lepiej odsłonimy prawdę o człowieku. Człowiek tłumaczony przez „byle jaki” dramat nadal pozostaje nieznany.

Tischner widział złożoność i tajemniczość tematu, który zgłębiał przez całe życie. Tym zapewne można tłumaczyć zwroty w jego myśleniu: cały czas chodzi o wyjaśnienie człowieka, ale trzeba znaleźć właściwy język. Przed wskazanymi przeze mnie wcześniej okresami w filozofii człowieka Tischnera był przecież jeszcze jeden: wyniesiony z seminarium język tomizmu. Tischner dość szybko zauważył jego nieprzydatność w opisie ludzkiego doświadczenia ${ }^{42}$. Kolejne poszukiwania są zatem cały czas próbą szukania języka, by wyrazić człowieka: z jego zewnętrznością i ukrytymi głębinami, z jego prostotą i tajemnicą jednocześnie.

Do tego celu Tischner potrzebuje swoich „ciemnych metafor”. Nie tłumaczy problematyki człowieka na alegoryczny język innej siatki pojęć, choć z pozoru tak to może wyglądać: świat to scena; relacje z ludźmi to dramaty itd. On zespala dwa „ciemne” pojęcia w jednym uścisku. Metafora nie wzlatuje do nieba i nie wraca $\mathrm{z}$ niego odciążona - w czym

${ }_{41}$ Zob. P. Ricoeur, Symbolika zła, dz. cyt., s. 19n.

42 Zob. Spotkanie. Z ks. Józefem Tischnerem rozmawia Anna Karoń-Ostrowska, Kraków 2003, s. 41, 55n. 
Tischner widzi zagrożenie dla metaforyzacjii ${ }^{43}$. Tego chyba się obawia, z rzadka sięgając po arsenał potocznych pojęć, takich jak choćby „plama”. Ten uścisk metafory jest jeszcze głębszy: pieśń, dramat, śmierć (jeśli traktujemy ją ontologicznie, a nie ontycznie) są same nie do pomyślenia bez człowieka. A plama i jaskinia tak. A zatem te Tischnerowskie metafory są zrośnięte z człowiekiem nie z nadania Tischnera, tylko z samej swej natury. To sprawia, że jednym z celów filozofii dramatu - traktowanej nawet jako intelektualne narzędzie do wyświetlenia pewnych fenomenów ludzkiego losu - musi być również praca wokół dramatu, gdyż bez niej owo wyświetlenie się nie powiedzie.

\section{Logos metafory}

Celem tego szkicu była próba pokazania nie tego, CO Józef Tischner napisał o człowieku, ale raczej JAK to formułował. Szata językowa okazała się nie tylko narzędziem, ale metodą wynikającą z przeświadczeń o charakterze metafizycznym. Myślenie $\mathrm{z}$ wnętrza metafory wyrasta bowiem z przekonania, że „Metafora, symbol nie są zjawiskami przypadkowymi w myśleniu radykalnym, lecz wręcz przejawami jego radykali$\mathrm{zmu}^{\prime \prime 4}$. Radykalizm ten to jednocześnie zgoda na to, by nie zawładnęła myśleniem chęć zbyt łatwego rozjaśniania, doprecyzowania i ujednoznacznienia. Są takie miejsca $\mathrm{w}$ myśleniu, które można myśleć tylko „Z wnętrza metafory”. Metafora nie jest więc tutaj jakimś zewnętrznym względem rzeczy myślenia wyrazem językowym, lecz czymś, co jest u podstaw tego myślenia.

Jednocześnie w metaforach daje się uchwycić ich wewnętrzny logos, pewną strukturę, która jest niezwykle precyzyjna. Szczególny logos zawiera się w metaforach samego Tischnera, który myśli o człowieku $\mathrm{z}$ wnętrza pojęć tak niejednoznacznych i zagadkowych, jak „dramat”, „pieśn" czy „śmierć”. W jego filozofowaniu pojęcia te zostają zespolone z pojęciem człowieka bardzo silną i jednocześnie nie do końca

43 Zob. J. Tischner, Myślenie z wnętrza metafory, dz. cyt., s. 502.

44 Tamże, s. 504. 
przeniknioną relacją: aby opisać człowieka, trzeba sięgnąć do metafory dramatu, ale żeby to zrobić, trzeba przywrócić pojęciu "dramat" właściwy ciężar gatunkowy. Jak to zrobić? Tischner pokazuje to w całej Filozofii dramatu: opisuje człowieka z wnętrza metaforyki dramatycznej, pokazując rozmaite węzłowe doświadczenia jego życia: dramat kuszenia, dramat prawdy, dramat piękna. Dzięki ujęciu tych fenomenów w nową symbolikę odsłaniają się ich wewnętrzne napięcia i powiązania, które wcześniej być może nie były widoczne. Jednocześnie każda z tych analiz przywraca dramatowi gatunkowy ciężar. Obydwa bieguny metafory są więc sobie niezbędne. Podporządkowanie jednego $\mathrm{z}$ nich drugiemu - co może sugerować rozróżnienie na „symbolizowane i „symbolizujące" - nie jest takie proste, jak w przypadku metafor, które sięgają do potoczności. Bieguny metafor Tischnera żyją dzięki sobie, z każdym zwrotem myślenia są ze sobą trwalej zespolone.

Powyżej przytoczone zostały trzy metafory, którymi w różnych okresach swego filozofowania o człowieku posługiwał się Tischner. Każdą z nich można by przeanalizować szczegółowo, by wychwycić głębsze struktury tego „logosu metafory”. Można by też wskazać wiele innych metafor: twarzy, domu, kryjówki itd., które dopełniają Tischnerowskie uniwersum symboli. To wszystko zadania przekraczające ramy niniejszego szkicu. Co pozostaje? Silne przekonanie, że Tischner jest ciągle przed nami, że potrzebna jest nowa próba całościowego odczytania jego filozofii człowieka, która wyrośnie z gruntownie przemyślanej logiki (czy też może raczej: dialektyki) Tischnerowskich metafor. Ta próba jest ciągle jeszcze przed nami. 